\title{
Surgeon educator perspectives of implementing a National Undergraduate Curriculum in otolaryngology
}

Andrew Hall ( $\sim$ andyhall07@googlemail.com )

Royal National Throat Nose and Ear Hospital https://orcid.org/0000-0002-4134-661X

Huw Jones

Royal National Throat Nose and Ear Hospital

Alam Hannan

Royal National Throat Nose and Ear Hospital

Research article

Keywords: National Curriculum; Otolaryngology; Undergraduate medical education

Posted Date: October 3rd, 2019

DOI: https://doi.org/10.21203/rs.2.15501/v1

License: (1) (i) This work is licensed under a Creative Commons Attribution 4.0 International License.

Read Full License 


\section{Abstract}

\section{Background}

The General Medical Council will be implementing a national examination for all UK medical students in 2022. Our aim was to review surgeon educator perceptions on the future implementation of an associated undergraduate national curriculum in otolaryngology within a UK School of Surgery.

\section{Methods}

A mixed methods study was performed to assess ENT surgeon educator perspectives of a change to a national curriculum in ENT. Responses were reviewed with respect to teaching content, quality and student experience with degree of agreement assessed with Likert scoring. Associated qualitative focus group sessions were performed and responses underwent detailed thematic analysis according to grounded theory.

\section{$\underline{\text { Results }}$}

A response rate of $50 \%$ was achieved with twenty-one participants analysed working in fourteen hospitals. These held an average of eight years undergraduate teaching experience. These showed strong agreement believing implementation of a national curriculum would improve the standard of teaching delivered at a personal, institutional and national level. There was also agreement on a minimum baseline for teaching exposure by students. $95 \%$ of surgeon educators in otolaryngology were in support of future adoption of a change to a centralized national otolaryngology curriculum in contrast to conventional expectations of resistance. Further related themes were identified relating to the personal, institutional and specialty related factors influencing practical delivery of a national curriculum that can help shape this delivery.

\section{$\underline{\text { Conclusions }}$}

Evaluating the future implementation of a national curriculum in ENT from those involved in the regular practical delivery of undergraduate medical education was previously unassessed within the medical literature. A series of practical recommendations are made to assist the implementation of a national ENT curriculum in contrast to the current locally led system. These were divided into areas of teaching content, teaching quality and student experience. A national curriculum appears to offer a philosophically accessible and popular re-imagining for future undergraduate otolaryngology training. Our findings aim to offer assistence to other similar surgical sub-specialties facing similar challenges internationally. 


\section{Background}

Historically, each UK medical school maintained a degree of individual autonomy in delivering a doctor following five years of intensive undergraduate study. The various medical schools, however, have held widely differing interpretations of the requisite underlying knowledge and skills that should be demonstrated and their financial distribution of resources. ${ }^{1-2}$. Traditional topics, e.g. anatomy, on which one medical school may spend a large amount of study time within the curriculum could be covered much more briefly elsewhere. ${ }^{3}$. Sub-specialist areas of medicine, such as ophthalmology or

otolaryngology, may be significantly under-represented within undergraduate teaching ${ }^{4-5}$. From 2022, the General Medical Council intends to implement a national examination for medical students. In keeping with this change in paradigm, the concept of an associated shift to a national curriculum has been a move considered broadly within the UK medical education literature and otolaryngology to unify undergraduate experience ${ }^{6-7}$.

Our aim was to review the perceptions on future implementation of an undergraduate national curriculum in otolaryngology within a UK Surgical training region. The focus of this initial study was on the specific perceptions of surgical educators as this process begins its ongoing development from theoretical concept to practical reality.

Surgeon educators represent an important group in the delivery of undergraduate teaching and are worthy of analysis for a number of reasons. They hold responsibilities for delivery of teaching to medical students on a weekly basis across a variety of hospital settings from lectures and tutorials to the bedside. They have a minimum experience in post-graduate teaching of medical students of five years. As such, they offer a unique and important insight into the challenges of undergraduate otolaryngology teaching 'on the front line' that can assist potential understanding as to how a national curriculum would best practically take shape. Additionally perceived loss of autonomy through implementation of a national curriculum and associated resistance to change was felt to to be most strongly represented within this cohort.

Teacher perceptions of the implementation process of this new strategy have not previously been examined and areas of attention were the potential impact on underlying teaching content, teaching quality and the student experience. Teaching content was defined as what knowledge/skills should be transmitted from teacher to student fundamentally, i.e. 'What they should know'.. Teaching quality was defined as the successful transmission of intended knowledge/skills from teacher to student.

\section{Methods}

The target sample selected for review were 42 surgeon educators, who were delivering regular undergraduate teaching within the North Thames (London) surgical training region. A purposive sampling approach was taken to obtain the viewpoints, experiences and perceptions of these teachers. An initial quantitative survey was constructed, assessing surgical educators perspectives of teaching content, 
quality and student experience with degree of agreement assessed with Likert scoring. Requisite ethical approval was obtained from the University of Leicester and local approval from the lead clinician overseeing undergraduate medical school teaching in otolaryngology.

A quantitative survey format was selected to obtain numerical data from a representative cohort as to their perception of applying a UK National Curriculum in otolaryngology. Quantitative data is a familiar format to the target audience of medical educators and surgeons who oversee teaching delivery. An internet-based system was utilized on this occasion (SurveyMonkey) for the collation of data. This collection tool allowed 'real-time' secure and anonymised data collection ${ }^{8}$.

The questionnaire contained three sections. The first section included relevant demographic information with gender, level of training and undergraduate medical school recorded. The second section was closed question survey instruments (open/closed) to collect data five-point Likert scale questions for measuring teacher's perspectives, while the third section was open-ended questions for teachers to express their concerns and opinions about implementation of a national curriculum. A small pilot study was conducted before the actual data collection to ascertain overall clarity of the research instrument, although no concerns arose.

The questionnaire (see Appendix 1) consisted of seven items of which five used a 5-point Likert scale to rank the responses. The scale ranged from 1 (Strongly Agree) to 5 (Strongly Disagree) and was used to categorize each surgeon educators response to the questions. To successfully implement a successful structural upheaval will require significant engagement with those delivering the curriculum to students. As such, uncertainty (a score of 3 ) is an equally important result than agreement or dissent ${ }^{9}$. Two questions were free-text areas allowing more detailed thoughts to be provided.

Subsequently, three separate focus group sessions of three to four individuals were adopted for qualitative evaluation ${ }^{10}$. Historically, small focus groups have been shown to have greater potential than larger focus group environments ${ }^{11}$. These were recorded, anonymised and immediately transcribed in full. The interviewees' opinions on National Curriculum and undergraduate otolaryngology teaching were explored through a thematic coding approach undertaken by the lead researcher, underpinned by grounded theory ${ }^{12}$. Anonymised transcription of the audio recording was typed and printed. Comments were manually separated using scissors, compared, grouped and categorized accordingly. Each separate focus group transcript was assessed in isolation, seeking to first identify codes that may lead to the creation of core categories. This process was then repeated for each of the three focus groups. Next, following assessment of the similarities and differences of the three focus groups, analogous codes and categories could be distilled further into discrete themes ${ }^{13}$. These then led to the eventual development of the thematic networks for the overall subject matter. Individuals were anonymised and referred to as T110 within the subsequent analysis.

\section{Results}




\section{Quantitative Data Analysis}

This was performed using both Microsoft Excel and SOFA statistics ${ }^{\text {TM }}$ packages. Parametric analysis was performed for the Likert scores as per recent work of Norman ${ }^{14}$, which clarified in his review the benefits over and above non-parametric tests. Median scores were used accordingly owing to the nonlinear format of the five-point Likert score ${ }^{15}$.

\section{Participant Characteristics}

An overall response rate of 50\% (21 individuals) was achieved, which compares favourably with similar otolaryngology curriculum surveys ${ }^{16}$. This improves the overall generalisability of the survey, while the response rate may in itself hold additional value, as engagement was on the basis of interest and perceived 'personal need'.

A breakdown of the individual surgeon educator's medical school attended and teaching style was reviewed. Our cohort showed a considerable variation in background with the 21 individuals attending 12 of the 33 recognised UK based medical schools. The three main medical school teaching styles were represented with $14 \%$ undertaking a problem-based approach as an undergraduate, whereas traditional and integrated approaches made up $43 \%$ each. The mean undergraduate teaching experience of this cohort was eight years, highlighting a high level of experience.

\section{a) Teaching Content}

A summary of the data (Table 1) suggests participants were very supportive of broad goals of standardising teaching content from topics, resources, practical experience and overall length of time for the programme. Surgeon educators appear overall to wish to preserve a degree of institutional and educator autonomy within the overall structure of the national curriculum. They were less supportive of more proscriptive initiatives in teaching provision, particularly those stating who (consultant-led) and how (setting/teaching method) would occur. Clarity and consistency in the overall vision is crucial to the success of large-scale institutional change in education and therefore the involvement of teaching stipulations other than specified content would need to be carefully considered ${ }^{17}$.

Table 2 highlights support for a broad range of distinct goals for a national curriculum in undergraduate otolaryngology. An essential principle of understanding a curriculum is assessment of its underlying aims in ensuring that the included content befits the intended purpose. Significant variation between the perceived aims of a curriculum as viewed by participants and the actual purposes of those implementing would likely manifest in poor overall delivery. A successful curriculum is one that when completed satisfies the original intentions behind its construction, essentially achieving its statement of intent ${ }^{18}$. It would appear for a National Curriculum to just focus on the teaching of otolaryngology that is required in general medical practice would be too narrow a target and more expansive goals would be welcomed by surgeon educators. 
The level of support by participants for a national curriculum in potentially improving not only their teaching but teaching within medical schools nationwide was strong. (Table 3) The interpretation of 'risk' from undertaking this process was also negligible, with only one individual feeling it could adversely affect teaching innovation and no one feeling it would negatively impact on teaching within their institution. These results appear to suggest within our school of surgery there is confidence in this mechanism as a potential conduit to institutional improvement.

\section{c) Student Experience}

Additionally, 19 surgeon educators felt that the students themselves would benefit from the implementation of a national curriculum; with 16 feeling it could improve overall access to educational resources. Interestingly, within higher education, much criticism has been made of the restrictive nature of national curricula ${ }^{19}$, but here there appears a degree of positivity and idealism as a method to advance teaching.

Classically, we acknowledge that more experienced staff are more reluctant to changes in established practices $^{20}$. Given the level of experience of the participants, it is interesting we witness only a third (33\%) who feel that a barrier to implementation would be at the level of the teaching staff themselves. Instead, what is demonstrated is that barriers are more likely to exist at the medical school level with lack of perceived need and incentive to motivate change in practice. All but two participants felt an absence of an over-arching authority to oversee the process, and perhaps given the literature demonstrating external involvement this would benefit from further promotion ${ }^{21}$. These findings, although small in scale, provide us with knowledge on where the perceived challenges to this potential change exist and therefore illustrate the areas in need of attention to overcome them.

Participants' responses to the question on whether they would support the implementation of a national undergraduate curriculum in otolaryngology was overwhelmingly supportive with $95 \%$ feeling they strongly agreed or agreed with the statement. Five percent were unsure with no disagreement as to the principle. This is an important aspect, given the level of influence the surgeon educators hold in the undergraduate teaching process.

\section{Qualitative Data Analysis}

A thematic coding approach undertaken by the lead researcher underpinned by grounded theory ${ }^{12}$. Anonymised transcription of the audio recording was typed and printed. Comments were manually separated using scissors, compared, grouped and categorized accordingly.

Each separate focus group transcript was assessed in isolation, seeking to first identify codes that may lead to the creation of core categories. This process was then repeated for each of the three focus 
groups. Subsequently, following assessment of the similarities and differences of the three focus groups, analogous codes and categories could be distilled further into discrete themes ${ }^{13}$. These then led to the eventual development of the thematic networks for the overall subject matter. Individuals were anonymised and referred to as T1-10 within the subsequent analysis. Crucially, the participating individuals represent a mixture of sexes representative of modern otolaryngology training in 2017 with $40 \%$ female ${ }^{22}$ and an overall experienced cohort in undergraduate education with median time participating in regular undergraduate teaching of eight years. A summary of the thematic analysis process is shown in Figure 5.

What was clearly displayed throughout was referential loyalty to the brand of medicine, the recognised rites and rituals that determine the process of becoming a doctor. The discussions were all focused on undergraduate teaching with a national curriculum in otolaryngology and yet conversations naturally evolved towards the broader duty of training in producing a competent doctor first and foremost. Thoughts of modernisation are tempered by historical faith in the 'process' of medical school.

Using grounded theory, a central unifying feature is required. Here, this perhaps best displayed in the individual teacher's perceptions, reflecting their personal sense of 'belonging' and identity to the various sub-groups they occupy. The individual considers their role as 'Doctor and representative of Medicine'; 'Surgeon representing the Specialty of otolaryngology'; 'Representative of X Medical School' or 'Teacher to a Student'. Interpreting where an Undergraduate National Curriculum in otolaryngology 'fits in' to this structure forces thoughts to crystallize and decision-making according to their own personal prioritization of their own defining preferred identity.

\section{Discussion}

In 2015 , there were 40,078 medical students training within the 33 UK medical schools ${ }^{23}$, and as such the implications of any large-scale changes to training should be considered with reference to the cumulative numbers involved. Otolaryngology pathology contributes a very large proportion of the day-to-day cases seen by doctors working as general practitioners in the UK. Previous analysis suggests this approximates to $25 \%$ of all presentations to primary care ${ }^{6}$. When reviewed, this corresponds to a figure of 850,000 primary care patient encounters a year within the UK ${ }^{24}$.

Multiple studies have shown wide variation in the overall provision of undergraduate otolaryngology at UK medical schools. On average, less than eight days of teaching were provided to students over a fiveyear period, while $22 \%$ of individuals had no otolaryngology clinical attachment within their UK undergraduate clinical training ${ }^{25}$. Powell et al showed undergraduates were significantly less confident with otolaryngology history-taking, examination and management, as compared to cardiology clinical competencies $(p<0.001)^{26}$. Interestingly, the same study demonstrated that teaching modalities with a lower perceived educational value were generally offered more frequently than those with a higher perceived educational value. This seems to highlight deficiencies in the teaching quality as well as content within otolaryngology. Dramatically, Clamp et al highlighted that approximately $33 \%$ of general 
practitioners in South West England had no hospital experience or any postgraduate training related to otolaryngology at all ${ }^{27}$.

Staff engagement is crucial in implementing the changes required for a nationally driven curriculum. Curriculum creation is only a relatively small part of the overall process, and dissemination and support in delivery is key. Overall, the need to seek staff engagement and involvement in the process of change mirrors the Japanese Toyota Production Factory System concept of 'Jidoka'28. Here, we are seeking to identify the potential problems of a national curriculum 'at source' through the individuals most acutely involved in the educational 'production line'. As such, the data identifies specific barriers to the potential implementation of a national curriculum.

Current work has sought to map the otolaryngology curriculum at UK Medical Schools in order to try and better facilitate any potential adoption in terms of content ${ }^{7}$. Constable et al produced survey data looking at perceived otolaryngology knowledge amongst non-otolaryngology doctors, which was felt to be universally poor and in need of further attention ${ }^{16}$. Overall, there has been a predominant focus on what students should know, but much less emphasis on how they should come to know it.

Outlining a curriculum involves simultaneously setting national standards in undergraduate otolaryngology education. This is subject to concerns as to the overall level selected. Acceptance of a diminished standard of student understanding or practical ability could create an arbitrary high pass rate, but clearly this could have serious ramifications for future patient care and damage trust in the very profession of medicine ${ }^{29}$. A potential analogous concern at the level of the medical schools themselves is that their overall academic standards and associated expectations may vary and adoption of a universal standard may be actually below their preceeding expectations of what is satisfactory. This was identified both through a systematic review and the GMC consultation exercise ${ }^{23,30}$.

Clearly, to harmoniously implement a nationally driven curriculum that would result in a significant pedagological and organisational paradigm shift would not be without obstacles on a local level. Identifying that these barriers appear to exist at the institutional level and indeed postulated potential solutions for these as this analysis has done is a key step. Substantial 'buy in' at local level for the initiative is essential. It is important to recognise, however, at the level of

those personally undertaking the delivering the curriculum, with $95 \%$ of those in favour of the initiative, that this has already occurred to a degree. Localism may hold a value in driving innovation, yet this should not be at the expense allowing fundamental deficiencies to continue within a dysfunctional system. Medical training appears too intrinsically valuable not to carefully police and if correctly managed homogenization of experience will be for the betterment of student experience.

The large-scale reorganization of a national curriculum would be a convenient time for departments to perform local rationalization and assessment of their provided teaching. It is right to question dogma of established practice and reframe it in the context seeking proven successful practice. It is possible that 
additional promotion on effective teaching delivery could act as a hegemonic gauntlet thrown down to medical school teachers locally to inspire excellence.

This study is limited in involving a sample of surgeon educators based in one training region, working in fourteen different hospitals. The opinions gleaned are however obtained from the alumni of twelve UK medical schools with an associated variety of undergraduate experience. Future large-scale involvement of medical school academic staff and students themselves are important analogous steps to prepare for successful adoption of an otolaryngology national curriculum yet this group are integral to the perceived success or failure of this change.

At present, this is the first attempt to seek the perspectives of implementation of a national curriculum in otolaryngology and how this may be best achieved by those involved in its delivery. Our findings would appear to be transferable to other similar surgical subspecialties e.g. ophthalmology or urology as well as geographically to other surgical training schemes internationally.

\section{Conclusions}

Combining the quantitative and qualitative analysis from our participants, we can draw some initial recommendations. Percentages and or median Likert scores obtained were used for interpretation of the quantitative data, while the outcomes of the thematic analysis were used for the qualitative data.

What are the perceptions of medical school educators on suitable teaching content in delivering an undergraduate otolaryngology National Curriculum?

The goals of a national curriculum were felt to be to teach students otolaryngology for future practice as a doctor, provide aspirational exposure, support educational resources, limit variation and set amount of time for teaching. A National Curriculum if adopted should be composed with emphasis on providing 'guidance' on content, avoiding being overly paternalistic in its construction. It is felt this would provide the best opportunity to maximize innovation and avoid the national curriculum itself limiting excellent practice above the minimum baseline. There was agreement on a minimum baseline for teaching exposure by students, national examination standards, involvement of practical skills teaching and provision of standardized teaching materials. Formal stipulations on the amount of consultant led teaching time, method of teaching delivery, teaching setting or requirement for simulation training was met with uncertainty by the assessed cohort. On an individual level, daily work and on call life would be improved through strengthening otolaryngology undergraduate training in the long term. Teachers in otolaryngology are keen to place their specialty within the broader goal of creating 'good doctors'. There was recognition that otolaryngology represents a small (yet vital) cog in the machine and should not seek to over-develop otolaryngology training for the detriment of medical training in general.

What are the perceptions of medical school educators delivering an otolaryngology National Curriculum on teaching quality? 
It is believed by participants that adoption of a National Curriculum would improve the standard of teaching delivered at a personal, institutional and national level. At the School of Surgery, it was felt to be very unlikely to have an adverse effect on medical students or innovation in teaching delivered. There was belief that teachers' legitimacy as educators should be more transparent with a form of training in teaching necessary for those delivering undergraduate teaching in otolaryngology.

What are the perceptions of medical school educators delivering an otolaryngology National Curriculum on the student experience?

The importance of student experience to any widespread changes to the curriculum was viewed as key. A national curriculum in undergraduate otolaryngology was felt to be likely to improve the student experience and access to educational resources at our school of surgery. Barriers to delivery of implementation of a national curriculum for students were felt to be at an institutional rather than individual 'teacher' level. This would be through lack of local incentive, lack of central authority and lack of perceived necessity. These are areas that particularly require focus for potential successful delivery at our school of surgery working with key institutional stakeholders with support from external organizations is perceived to be useful in this regard.

Evaluating potential implementation of a national curriculum from those involved in the regular practical delivery of undergraduate medical education was previously unassessed within the medical literature. Strong agreement was shown to statements believing a national curriculum would improve the overall standard of teaching delivered at a personal, institutional and national level. There was also widespread agreement on a minimum baseline for teaching exposure by students, national examination standards, involvement of practical skills teaching and provision of standardized teaching materials. $95 \%$ of surgeon educators in otolaryngology were found to support the concept of a national undergraduate curriculum. Creating a National Curriculum is not a panacea to cure all 'ills' in current local otolaryngology teaching, but it does appear to offer a philosophically accessible and universally popular re-imagining for future undergraduate otolaryngology training.

\section{Declarations}

Ethical Approval: The project was approved by the University of Leicester educational leadership ethics committee and local approval from the lead clinician overseeing undergraduate medical school teaching within otolaryngology. Informed consent was sought for participants with anonymity safeguarded.

Consent for publication: Not applicable

Availability of data: The datasets used during the current study are available from the corresponding author on reasonable request.

Declaration of Competing Interests: Nil

Funding: Nil

Page 10/19 
Authors Contributions: ACH designed/acquired data/interpreted and drafted the manuscript. HJ was involved in analysis and manuscript revision. SAH was involved in design/data acquisition and manuscript revision. All authors gave approval of the final manuscript.

Acknowledgements:Grateful to all study participants for their time and considered thought in their participation.

Authors Information

$\mathrm{ACH}$

Specialist registrar in Otolaryngology in North Thames, London with an interest in medical education. He has attended Boston Children's Hospital to undertake simulation research and has recently completed an MSc in educational leadership.

HJ

Specialist Registrar in Otolaryngology North Thames, London with an active profile in teaching. He has been involved in national course development within ENT.

SAH

Consultant Otolaryngologist. Undergraduate lead in Otolaryngology at University College Hospital, London.

\section{List Of Abbreviations}

ENT $=$ Ear, Nose and Throat

$\mathrm{GMC}=$ General Medical Council

\section{References}

${ }^{1}$ McManus I. C. (2003) Medical school differences: beneficial diversity or harmful deviations? Qual Saf Health Care,12:324-325

${ }^{2}$ Wyneford-Thomas, D. (2012) Organization and Management of Medical Schools- A survey of ten universities. Retrieved from http://www.medschools.ac.uk/Publications/Pages/default.aspx (Accessed $11 / 3 / 19)$

${ }^{3}$ Howe A, Campion P, Searle J, et al. (2004) New perspectives-approaches to medical education at four new UK medical schools. BMJ,329:327-32. 
${ }^{4}$ Fung K. (2015) Otolaryngology-head and neck surgery in undergraduate medical education: advances and innovations. Laryngoscope; 125(suppl 2):S1-14

${ }^{5}$ Farooq, M., Ghani, S. and Hussain, S., 2016. Prevalence of Ear, Nose \& Throat diseases and Adequacy of otolaryngology training among General Physicians. International Journal of Pathology, 14(3), pp.113115

${ }^{6}$ Lloyd S, Tan ZE, Taube MA, Doshi J. (2014) Development of an Otolaryngology undergraduate curriculum using a Delphi survey. Clin Otolaryngology,39:281-8

${ }^{7}$ Steven R.A, Mires G.J, Lloyd, S. K., McAleer S. (2017) An undergraduate Otolaryngology curriculum comparison in the United Kingdom using a curriculum evaluation framework. Clinical Otolaryngology 42(5):963-968.

${ }^{8}$ Gill F.J., Leslie, G.D., Grech, C. Latour, J.M. (2013) Using a web-based survey tool to undertake a Delphi study: application for nurse education research. Nurse Education Today;33(11):1322-8

${ }^{9}$ Chyung, S. Y., Roberts, K., Swanson, I. and Hankinson, A. (2017) Evidence-Based Survey Design: The Use of a Midpoint on the Likert Scale. Perf. Improv.,, 56: 15-23.

${ }^{10}$ Gill P, Stewart K, Treasure E, Chadwick B. (2008) Methods of data collection in qualitative research: interviews and focus groups. Br Dent J 204:291-5

${ }^{11}$ Krueger, R., \& Casey, M. (2000). Focus Groups: A Practical Guide for Applied Research (3rd ed.). Thousand Oaks, CA: Sage Publication.

${ }^{12}$ Glaser, B.G and Strauss, A. (1967) Discovery of Grounded Theory. Strategies for Qualitative Research. Sociology Press, London, UK.

${ }^{13}$ Braun V, Clarke V. Successful Qualitative Research. London: Sage, 2013

${ }^{14}$ Norman G. Likert scales, levels of measurement and the "laws" of statistics. Adv Health Sci Educ Theory Pract. 2010 Dec;15(5):625-32

${ }^{15}$ Sullivan, G. M., Artino, A. R. (2013) Analyzing and interpreting data from likert-type scales. Journal Graduate Medical Education 5(4):541-2

${ }^{16}$ Constable, J., Moghul, G., Leighton, P., Schofield, S., \& Daniel, M. (2017). Prioritising topics for the undergraduate Otolaryngology curriculum. The Journal of Laryngology \& Otology, 131(7), 631-639

${ }^{17}$ Ansell, B. (2008). University Challenges: Explaining Institutional Change in Higher Education. World Politics, 60(2), 189-230. 
${ }^{18}$ Prideaux, $D(2003) A B C$ of learning and teaching in medicine: Curriculum design. $B M J, 326,268-270$

${ }^{19}$ Curtner-Smith, M. (1999) The More Things Change the More They Stay the Same: Factors Influencing Teachers' Interpretations and Delivery of National Curriculum Physical Education Sport, Education and Society $4: 175-97$

${ }^{20}$ Ungar, O. A., Magen, N. (2014) Teachers in a changing world: attitudes toward organizational change. Journal of Computers in Education 1(4) 227-249.

${ }^{21}$ General Medical Council (2017) Medical Licensing Assessment. London, UK. ${ }^{22}$ McNally SA. (2007) Competition ratios for different specialties and the effect of gender and immigration status. Journal of the Royal Society of Medicine,101(10):489-492

${ }^{23}$ General Medical Council (2015) The state of medical education and practice in the UK report: London, UK.

${ }^{24} \mathrm{NHS}$ England Improving general practice-a call to action. (August 2013) https://www.england.nhs.uk/wp-content/uploads/2013/09/igp-cta-evid.pdf (accessed Feb 11, 2019).

${ }^{25}$ Khan M.M, Saeed, S.R. (2012) Provision of undergraduate otorhinolaryngology teaching within General Medical Council approved UK medical schools: what is current practice? Journal of Laryngology and otology 126(4):340-4

${ }^{26}$ Powell J, Cooles FA, Carrie S, Paleri V. Is undergraduate medical education working for Otolaryngology surgery? A survey of UK medical school graduates. J Laryngol Otol. 2011 Sep;125(9):896-905.

${ }^{27}$ Clamp PJ, Gunasekaran S, Pothier DD, et al. (2007) OTOLARYNGOLOGY in general practice: training, experience and referral rates. The Journal of Laryngology \& Otology;121:580-585

${ }^{28}$ Stecher, B. and Kirby, S. (2004) Organisational Improvement and Accountability: Lessons for education from other sectors RAND; California; USA

${ }^{29}$ Batmanabane G. (2013) When angels fall...are we lowering the standards of medical education in India? Journal of Pharmacology \& Pharmacotherapeutics; 4(1):1-3.

${ }^{30}$ Ferguson GR., Bacila IA, Swamy M. (2016) Does current provision of undergraduate education prepare UK medical students in Otolaryngology? A systematic literature review. BMJ Open 2016;6:010054.

\section{Tables}

Table 1: Percentage of respondent's agreement with statements describing potential teaching content in a national undergraduate otolaryngologycurriculum. (Teaching Content) 


\begin{tabular}{|c|c|c|}
\hline $\begin{array}{c}\text { 'I believe a national curriculum in undergraduate } \\
\text { otolaryngology should include...' }\end{array}$ & $\begin{array}{c}\text { Percentage Agreement } \\
\text { with statement } \\
\text { (Likert score } 1 \text { or } 2 \text { ) }\end{array}$ & $\begin{array}{c}\text { Median } \\
\text { Likert Score }\end{array}$ \\
\hline Designated Teaching content (specified topics) & $100 \%(21)$ & 1 \\
\hline $\begin{array}{c}\text { Designated assessment objectives (national examination } \\
\text { standards) }\end{array}$ & $81 \%(17)$ & 2 \\
\hline $\begin{array}{l}\text { Minimum time allocation in teaching within specialty (i.e. } \\
\text { number of days in otolaryngology) }\end{array}$ & $86 \%(18)$ & 1 \\
\hline $\begin{array}{c}\text { Minimum time allocation in teaching according to topic (i.e. } \\
\text { epistaxis) }\end{array}$ & $47 \%(10)$ & 3 \\
\hline Stipulated hours of consultant-led teaching delivered & $43 \%(9)$ & 3 \\
\hline $\begin{array}{l}\text { Stipulated method of teaching delivery (e.g. small group or } \\
\text { lecture }\end{array}$ & $62 \%(13)$ & $\overline{2}$ \\
\hline $\begin{array}{c}\text { Stipulated teaching setting (clinical environment/tutorial } \\
\text { room) }\end{array}$ & $57 \%(12)$ & $\overline{2}$ \\
\hline Stipulated simulation training & $47 \%(10)$ & $\overline{3}$ \\
\hline Stipulated practical/surgical skills-based training & $76 \%(16)$ & 2 \\
\hline $\begin{array}{c}\text { Provision of standardised student learning materials (e.g. } \\
\text { handbook) }\end{array}$ & $81 \%(17)$ & 2 \\
\hline
\end{tabular}

Table 2: Percentage of respondents agreeing or strongly agreeing with statements describing the intended aims of implementing a national undergraduate otolaryngology curriculum.

\begin{tabular}{|c|c|c|}
\hline 'Goals of a national curriculum should be to...' & $\begin{array}{c}\text { Percentage } \\
\text { Agreement with } \\
\text { statement } \\
\text { (Likert score 1 or 2) }\end{array}$ & $\begin{array}{c}\text { Median } \\
\text { Likert } \\
\text { Score }\end{array}$ \\
\hline $\begin{array}{c}\text { Teach students essential otolaryngology for future practice as a } \\
\text { doctor (in any specialty) }\end{array}$ & $100 \%(21)$ & 1 \\
\hline Teach students surgical skills & $57 \%(12)$ & 3 \\
\hline $\begin{array}{c}\text { Provide exposure to specialty of otolaryngology as a potential } \\
\text { future career option }\end{array}$ & $95 \%(20)$ & 1 \\
\hline $\begin{array}{c}\text { Limit variation and provide a consistent learning experience for } \\
\text { students in otolaryngology }\end{array}$ & $86 \%(18)$ & 1 \\
\hline $\begin{array}{c}\text { Provide national guidance to support provision of educational } \\
\text { resources to the specialty }\end{array}$ & $90 \%(19)$ & 1 \\
\hline $\begin{array}{c}\text { Provide national guidance to support time given to the specialty } \\
\text { in context of varying medical school priorities. }\end{array}$ & $86 \%(18)$ & \\
\hline
\end{tabular}


Table 3: Percentage of respondent's agreement with statements describing the likely outcomes of implementing a national undergraduate otolaryngology curriculum on Teaching Quality and Student Experience (in bold)

\begin{tabular}{|c|c|c|}
\hline $\begin{array}{l}\text { 'Implementing a national curriculum in } \\
\text { undergraduate otolaryngology will...' }\end{array}$ & $\begin{array}{l}\text { Percentage Agreement } \\
\text { with statement } \\
\text { (Likert score } 1 \text { or } 2 \text { ) }\end{array}$ & $\begin{array}{l}\text { Median Likert } \\
\text { Score }\end{array}$ \\
\hline lead to an improvement in my teaching & $86 \%(18)$ & 1 \\
\hline $\begin{array}{c}\text { lead to improvement in teaching quality at my } \\
\text { institution }\end{array}$ & $90 \%(19)$ & 2 \\
\hline lead to improvement in teaching quality nationally & $86 \%(18)$ & 1 \\
\hline $\begin{array}{l}\text { adversely affect experience of medical student teachers } \\
\text { at my institution }\end{array}$ & $0 \%(0)$ & 4 \\
\hline adversely affect innovation in teaching & $5 \%(1)$ & 4 \\
\hline Improve the student experience at my institution & $90 \%(19)$ & 1 \\
\hline Improve access to educational resources & $76 \%(16)$ & 2 \\
\hline
\end{tabular}

Table 4: Percentage of respondents agreeing or strongly agreeing with statements describing the possible barriers of implementing a national undergraduate otolaryngology curriculum.

\begin{tabular}{|c|c|c|}
\hline Potential Barrier Described & $\begin{array}{c}\text { Percentage Agreement } \\
\text { with statement } \\
\text { (Likert score 1 or 2) }\end{array}$ & $\begin{array}{c}\text { Median Likert } \\
\text { Score }\end{array}$ \\
\hline $\begin{array}{c}\text { Reluctance by medical student teachers to engage } \\
\text { (otolaryngology surgeons) }\end{array}$ & $33 \%$ (7) & 3 \\
\hline $\begin{array}{c}\text { Reluctance by medical school to engage (Lack of } \\
\text { perceived need) }\end{array}$ & $81 \%(17)$ & 3 \\
\hline $\begin{array}{c}\text { Fear of loss of individual medical school } \\
\text { autonomy/identity }\end{array}$ & $48 \%(10)$ & 2 \\
\hline $\begin{array}{c}\text { Lack of local incentive } \\
\text { Lack of central authority to drive national changes at a } \\
\text { local level }\end{array}$ & $76 \%(16)$ & 2 \\
\hline
\end{tabular}


Figure 5: Thematic network displaying the personal, institutional and external factors related to use of a National Curriculum in undergraduate otolaryngology 


\begin{tabular}{|c|c|c|c|}
\hline Theme & Section & Sub-section & Illustrative Summary/Quote \\
\hline \multirow[t]{3}{*}{$\begin{array}{l}\text { Personal Factors } \\
\text { 'Individuals } \\
\text { perception on their } \\
\text { role as a teacher } \\
\text { using a national } \\
\text { curriculum in } \\
\text { otolaryngology' }\end{array}$} & $\begin{array}{l}\text { Teaching } \\
\text { Content }\end{array}$ & $\begin{array}{c}\text { 'Minimum } \\
\text { Expected } \\
\text { Knowledge' } \\
\\
\text { 'Re-inventing } \\
\text { the wheel' } \\
\\
\text { 'Avoiding } \\
\text { divisive } \\
\text { variation' } \\
\\
\text { 'Improved } \\
\text { post-graduate } \\
\text { training' }\end{array}$ & $\begin{array}{l}\text { 'Formalising minimum knowledge base would be } \\
\text { positive as a teacher...' (T4). } \\
\text { No participant suggested via the focus groups } \\
\text { that the present curriculum was currently } \\
\text { sufficient. } \\
\text { 'It would need to be more than national } \\
\text { guidelines that are then not used, not just } \\
\text { content on a website'. (T3) } \\
\text { 'May be helpful to remove some of the } \\
\text { individuality and autonomy from local trainers... } \\
\text { you realize how much variation exists the more } \\
\text { you teach' (T11) } \\
\text { 'It allows realistic expectations for me as a } \\
\text { trainer to know what has been provided before, } \\
\text { avoiding over and under expectations given } \\
\text { movement of students across the country as } \\
\text { part of their training' (T6) }\end{array}$ \\
\hline & $\begin{array}{l}\text { Teaching } \\
\text { Quality }\end{array}$ & $\begin{array}{l}\text { 'Correct } \\
\text { individuals } \\
\text { delivering } \\
\text { teaching' } \\
\text { 'Ensuring } \\
\text { trained } \\
\text { teachers' }\end{array}$ & $\begin{array}{l}\text { 'Important that personnel is considered...(non- } \\
\text { clinicians) can't deliver the teaching on } \\
\text { microscopic examination of the ear etc that we } \\
\text { can' (T3) } \\
\text { 'you need to make sure you have had training in } \\
\text { teaching. Not all doctors are good teachers, we } \\
\text { need training' (T1) }\end{array}$ \\
\hline & $\begin{array}{c}\text { Student } \\
\text { Experience }\end{array}$ & $\begin{array}{l}\text { 'Assisting } \\
\text { Aspirations' } \\
\text { 'Adjusting to } \\
\text { loss of } \\
\text { apprenticeship' }\end{array}$ & $\begin{array}{l}\text { There needs to be an aspirational element, } \\
\text { explicitly built in to the syllabus...to tailor } \\
\text { towards the common but also allow those to } \\
\text { explore other interests is the frisson of medical } \\
\text { education' (T2) } \\
\text { 'it always was an apprenticeship model... } \\
\text { learning by community, now where is the } \\
\text { community owing to shift work etc?...I don't } \\
\text { think it can work like that anymore' (T3) }\end{array}$ \\
\hline $\begin{array}{c}\text { Institutional Factors } \\
\text { 'Individuals } \\
\text { perception of } \\
\text { medical school } \\
\text { institutions using a } \\
\text { national curriculum } \\
\text { in otolaryngology }\end{array}$ & $\begin{array}{l}\text { Teaching } \\
\text { Content }\end{array}$ & $\begin{array}{l}\text { 'Keeping it } \\
\text { flexible' } \\
\text { 'Medical } \\
\text { School } \\
\text { Dialogue' } \\
\text { 'National } \\
\text { Resource } \\
\text { Provision' }\end{array}$ & $\begin{array}{l}\text { 'otolaryngology is fairly compact which means it } \\
\text { would be fairly easy to deliver top } 10 \\
\text { presentations to cover...we are actually better } \\
\text { suited than many broader specialties' (T8) 'You } \\
\text { would need to emphasise a third of GP practice } \\
\text { is in otolaryngology' (T4) 'focus on what a day } 1 \\
\text { F1 should know' (T5) } \\
\text { 'Important to leave room for interpretation.' } \\
\text { (T8) 'very strongly against it being too } \\
\text { dogmatic' (T3) } \\
\text { 'It is in our vested interest as a specialty to be } \\
\text { more involved and be part of the University's } \\
\text { agenda' (T9) }\end{array}$ \\
\hline
\end{tabular}




\begin{tabular}{|c|c|c|c|}
\hline & & & $\begin{array}{l}\text { 'Delivery of resources may prove more effective } \\
\text { through a central process...you could develop } \\
\text { online resources and roll out to an } \\
\text { undergraduate setting' (T5) }\end{array}$ \\
\hline & $\begin{array}{l}\text { Teaching } \\
\text { Quality }\end{array}$ & $\begin{array}{l}\text { 'Institutional } \\
\text { leadership' } \\
\text { 'Failure of } \\
\text { medical } \\
\text { student } \\
\text { teaching' }\end{array}$ & $\begin{array}{l}\text { 'Top-down approach filters down. It becomes a } \\
\text { habit, an ethos for all' (T6) (on Consultant } \\
\text { teaching) 'Recognising an SPA for Consultant } \\
\text { teaching would improve teaching productivity of } \\
\text { the unit- ensure it (National Curriculum) is } \\
\text { being used' } \\
\text { Lack of basic knowledge in otolaryngology is } \\
\text { impacting on on call and referral service' (Of } \\
\text { doctors in general) (T8) 'Already within our } \\
\text { time, the overall standard of knowledge appears } \\
\text { below expectation'. (T10) }\end{array}$ \\
\hline & $\begin{array}{c}\text { Student } \\
\text { Experience }\end{array}$ & $\begin{array}{l}\text { 'Autonomy } \\
\text { eroding } \\
\text { respect' } \\
\text { 'Influential } \\
\text { student } \\
\text { opinion' } \\
\text { 'Personal } \\
\text { experience to } \\
\text { combat } \\
\text { consumerism' }\end{array}$ & $\begin{array}{l}\text { 'It seems a societal thing- people feel they can } \\
\text { turn up when they want and get spoon fed' (T2) } \\
\text { 'Sitting at side of clinic isn't considered as value } \\
\text { any more' (T10) } \\
\text { 'Feedback for every placement decides where } \\
\text { medical students go...placements that didn't do } \\
\text { well were cut short...(a good curriculum) would } \\
\text { make a difference' (T8) } \\
\text { 'The best attachments, everyone knew the your } \\
\text { (the student's) name' (T1) } \\
\text { 'They (students) want one-to-one and bedside } \\
\text { teaching' (T10) }\end{array}$ \\
\hline $\begin{array}{c}\text { External Factors } \\
\text { Individuals } \\
\text { perception of use of } \\
\text { a national } \\
\text { curriculum with } \\
\text { respect to Specialty } \\
\text { of otolaryngology } \\
\text { Surgery }\end{array}$ & & $\begin{array}{l}\text { 'A persuasive } \\
\text { standard' } \\
\text { 'Timely context } \\
\text { for change' } \\
\text { 'Specialty as a } \\
\text { checkpoint' }\end{array}$ & $\begin{array}{l}\text { 'I don't think we have to wait for others } \\
\text { (national curricular in other surgical } \\
\text { subspecialties). I think things work because } \\
\text { there is a drive (within otolaryngology) to make } \\
\text { things happen' (T9) } \\
\text { 'It is in our vested interest as a specialty to be } \\
\text { more involved and be part of the University's } \\
\text { agenda'. (T8) Other linguistic terms frequently } \\
\text { used included 'power' and 'weight'. A } \\
\text { recognised standard gives local departments } \\
\text { more weight to take to medical school to } \\
\text { suggest change' (T4) } \\
\text { 'It may be it becomes the decision of others and } \\
\text { this should lead to us being more involved' (T4 } \\
\text { discussing options of a surgical subspecialty } \\
\text { national board exam) 'As otolaryngology we } \\
\text { need to invest in this so that our portion is well } \\
\text { thought out' (T5) } \\
\text { 'Who is best placed to decide what students } \\
\text { should know? Those teaching students or those } \\
\text { seeing what doctors don't know on a regular } \\
\text { basis or those doing both'. (T3) 'Important to } \\
\text { recognise medical student numbers are going }\end{array}$ \\
\hline
\end{tabular}




\begin{tabular}{|c|c|c|}
\hline & & $\begin{array}{l}\text { up, there is a risk of diluting the experience on } \\
\text { the basis of necessity' (T5) }\end{array}$ \\
\hline $\begin{array}{c}\text { Individuals } \\
\text { perception of use of } \\
\text { a national } \\
\text { curriculum with } \\
\text { respect to Medicine }\end{array}$ & $\begin{array}{l}\text { 'Preserving the } \\
\text { brand' }\end{array}$ & $\begin{array}{l}\text { 'Might have to be realistic in relation to time... } \\
\text { training weighted in relation to understanding } \\
\text { in general medicine/general surgery and } \\
\text { primary care' (T5) } \\
\text { 'It'd be difficult to work out how fits in' (with } \\
\text { other priorities) (T8) }\end{array}$ \\
\hline
\end{tabular}

